Acta vet. scand. 1967, 8, 301-323.

From the State Veterinary Serum Laboratory, Copenhagen, Denmark.

\title{
NECROTIZING INFECTIOUS ENTERITIS IN PIGLETS, CAUSED BY CLOSTRIDIUM PERFRINGENS TYPE C
}

II. INCIDENCE AND CLINICAL FEATURES*)

\author{
By \\ Peter H $\phi g h$
}

Necrotizing enteritis in newborn piglets caused by Cl. perfringens type $\mathrm{C}$ was first described by Field \& Gibson (1955) under the designation "Clostridium welchii infection".

A preliminary communication (Høgh 1965) reported the diagnosis of the first 2 cases of this disease in Denmark.

The Danish porcine subtype of $\mathrm{Cl}$. perfringens type $\mathrm{C}$ does not differ to any important extent from foreign porcine strains. A comparison between a few foreign and 20 Danish strains showed correlation in regard to biochemical characteristics and to production of the major lethal antigens $\alpha$ and $\beta$. A few differences in the minor antigens could be demonstrated, and the non- $x \delta \theta$ haemolysis test did not give constant results (H $\phi g h$ 1967).

In the present paper a report is given of the incidence of the disease in Denmark, together with a description of clinical findings, based on anamnestic data and on observations from an infection experiment and a spontaneous outbreak.

\section{Previous investigations}

Necrotizing enteritis in piglets caused by $\mathrm{Cl}$. perfringens type $\mathrm{C}$ has been described by English, Hungarian and American workers. A disease with corresponding clinical and autopsy findings

*) The work was supported by a grant from Bernhard Bangs Mindefond. 
was observed in piglets in Sowkhoses in the USSR by Bakhtin (1956), who stated Cl. perfringens type $B$ to be the cause.

Litter morbidity. During a period of 16 months Field \& Gibson found a litter morbidity in 2 herds of 25 and $14 \%$ respectively. Szent-Iványi \& Szabó (1956) reported that not all litters were affected, while Barnes \& Moon (1964) and Moon \& Bergeland (1965) stated the litter morbidity to be almost $100 \%$.

Mortality within litters. The mortality in affected litters is high. Field \& Gibson reported as average mortality 42 and $74 \%$ in affected litters from 2 herds respectively and Szent-Iványi \& Szabó a total mortality of 15.9 to $73.0 \%$ in 6 herds. Høgh (1965) found a variation from 12.5 to $83.3 \%$ in 9 litters from 2 herds.

Age at death. The majority of infected pigs die during the first week after birth. According to the British studies (Field \& Gibson) death occurred most frequently within the first 3 days of life, and according to the Hungarian material (Szent-Iványi \& $S z a b o ́$ ) from the third to the sixth day after birth. Occasionally death could occur after the second week of life. Moon \& Bergeland stated that pigs up to 1 month old may become infected.

Clinical signs. It is characteristic that piglets, which are apparently normal at birth, gradually become limp, stop sucking, and develop diarrhoea. There is often blood in the faeces (Field $\&$ Gibson), or the faeces may be greyish-yellow to whitish-grey, watery, sometimes frothy and foetid (Szent-Iványi \& Szabó). In an experimental study Field \& Goodwin (1959) found that not all piglets developed diarrhoea. When that symptom was present, the faeces could vary in colour from yellowish through all grades of blood-staining to a "port-wine" colour. Other clinical findings were bristly coat, dull skin and distended abdomen (Szent-Iványi $\& S z a b o ́)$. Moon \& Bergeland added to the symptomatology the observation of dehydration and depression. Szent-Iványi \& Szabó and Manninger (1960) reported that the temperature is elevated, while Barnes \& Moon found normal or subnormal temperatures. Field \& Goodwin reported that the disease is accompanied by hypoglycaemia, and, apart from the diarrhoea, the authors considered the clinical picture to be the result of hypoglycaemia and metabolic collapse.

Course of the disease. The disease generally takes an acute to peracute course and less frequently is subacute. In spontaneous cases Field \& Gibson reported the usual duration to be 24 to 36 hrs., Szent-Iványi \& Szabó 1 to 2 days, and Barnes \& Moon 12 to 
48 hrs. In experimental cases Field \& Goodwin found the first signs of diarrhoea $12 \mathrm{hrs}$. after inoculation, and deaths occurred from 17 to $41 \mathrm{hrs}$. after inoculation. The protracted course is extended over several days (Field \& Gibson, Szent-Iványi \& Szabó).

Prognosis. Barnes \& Moon stated that the prognosis is poor if the faeces are blood-stained, but that complete recovery may occur if there are no signs of blood. Szent-Iványi \& Szabó and $H \phi g h$ (1965) reported that all forms of curative antibiotics treatment and chemotherapy are without any effect.

\section{MATERIAL AND METHODS}

The description of clinical signs is based on anamnestic information concerning 32 herds of swine, supplemented by personal observations during a spontaneous outbreak and by the results of an infection experiment on newborn piglets. The clinical descriptions are to some extent based on a limited number of case histories, since not all of these gave adequate information.

Statements concerning litter morbidity and mortality within litters are based on data from 24 herds. Calculations are based on information about the litters born from the assumed onset of the disease until the diagnosis was established. Herds nos. 1, 4 and 6, where the disease was presumed to have existed for about 2,8 and 3 years respectively, are included in the calculation, though only the litters born most recently are accounted for.

Infection experiments. Out of a litter of 11 piglets (sow no. 14) 6 were inoculated orally 2 hrs. after birth with $2 \mathrm{ml}$ of a 6 -hour-old culture in "cooked meat medium" (infected piglets). The remaining 5 piglets were not inoculated (in-contacts). The strain of $\mathrm{Cl}$. perfringens type C (CWC 1) used for inoculation had been isolated from a piglet in herd no. 1 and stored in the freeze-dried state.

For the haematological examination, 2 other litters were included, viz. 5 piglets from sow no. 17 and 8 from sow no. 18 (normal piglets).

Blood sampling and stabilization. Blood $(4-5 \mathrm{ml})$ was taken from the anterior V. cava by the method described by Carle \& Dewhirst (1942), the first time before feeding colostrum, and thereafter at varying intervals until about $100 \mathrm{hrs}$. after birth. Needle no. 1403/12 (Acufirm) was used for bleeding.

Each blood sample was distributed into 3 tubes with $1 \mathrm{ml}$ in each of the first 2, and $2-3 \mathrm{ml}$ in the third. As stabilizer in the first tube a solution of $1 \mathrm{~g}$ sodium oxalate and $10 \mathrm{~g}$ sodium fluoride in $300 \mathrm{ml}$ distilled water was used in an amount of $0.6 \mathrm{ml}$ to $1 \mathrm{ml}$ blood. The fluid was evaporated by heating to $105-110^{\circ} \mathrm{C}$ before the tube was 
used. In the second tube triform (a mixture of a $10 \%$ solution of formalin and a $10 \%$ solution of EDTA) was used in an amount of 1 drop to $1 \mathrm{ml}$ blood. Heparin in the dried form in a concentration corresponding to $15-20$ units per ml blood was added to the third tube.

Blood glucose: Examination for blood glucose was made on plasma from blood stabilized with oxalate-fluoride. After removal of protein substances through precipitation with glycine-buffered perchloric acid and enzymatic digestion with KABI-reagent (glucose-oxidase, peroxidase and o-dianisidin), the content of glucose was determined spectrophotometrically (Hitachi Perkin-Elmer 139 UV-VIS spectrophotometer) at $450 \mathrm{~nm}$ against a glucose standard as described by Levin \& Linde (1962).

Blood urea. Examination for blood urea was made on plasma from heparinized blood. After removal of protein substances through precipitation with trichloracetic acid and treatment with medical charcoal to adsorb compounds capable of giving non-specific colour reaction with p-dimethylaminobenzaldehyde (Levine et al. 1961), the content of urea was determined spectrophotometrically at $440 \mathrm{~nm}$ against a urea standard as described by Brown (1959).

Haemoglobin. The haemoglobin content in heparinized blood was determined spectrophotometrically as oxyhaemoglobin by means of a "Haemotest II" (Testa Lab. A/S, Copenhagen).

Haematocrit (P.C.V.). Haematocrit was determined on heparinized blood by a micromethod using a $10 \mathrm{~cm}$ long tube with a diameter of $1 \mathrm{~mm}$. The tubes were centrifuged for $1 \mathrm{hr}$. at $1500 \times \mathrm{g}$.

Erythrocytes and leukocytes. Total red and white blood cell counts were made on a Coulter Counter Model F (Coulter Electronics, 'Ltd., England). The blood was stabilized by triform and diluted to $1: 50,000$ and $1: 500$ respectively.

Differential counting. This was made on smears prepared from heparinized blood and stained with May-Grünwald-Giemsa's stain. Numbers of lymphocytes and granulocytes were determined on the basis of the total leukocyte count and the percentage distribution of lymphocytes and granulocytes found by the differential counting.

\section{RESULTS}

Incidence. Since the first observation of necrotizing enteritis in piglets in Denmark in November 1963, the disease has been found in 32 herds with a total of 660 sows (status as at March 1, 1967). The geographical distribution of the infected herds will appear from Fig. 1. Twenty-two of the herds are in the southern part of Zealand, and $\mathbf{1 0}$ in a district east of Silkeborg and south of Aarhus in Jutland.

Size of herds. The size of the infected herds varied from 3 to 70 breeding sows. Eleven of the herds had less than 15, 12 had between 16 and 30 , and 9 had more than 30 breeding sows. 


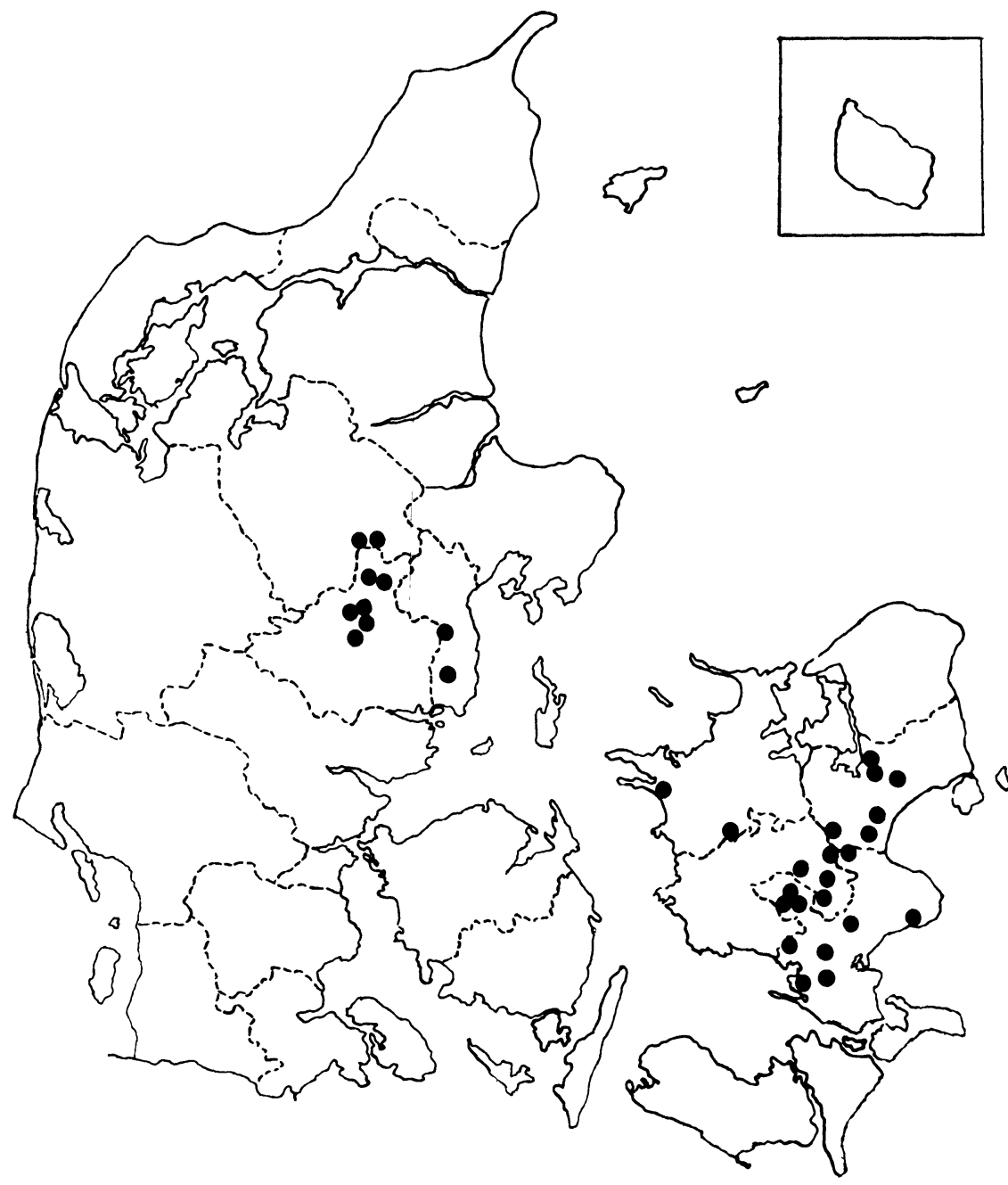

Figure 1. Geographical localization of herds with necrotizing infectious enteritis in piglets (status as at March 1, 1967).

\section{Clinical observations}

The spreading of the disease within a herd is illustrated through the observations made in herd no. 12. As will appear from Fig. 2, which shows the mortality up to weaning among piglets in this herd, there was a 2 to 3 times higher mortality in June, July and August than in the first 5 months of the year. According to the information available, the disease presumably 


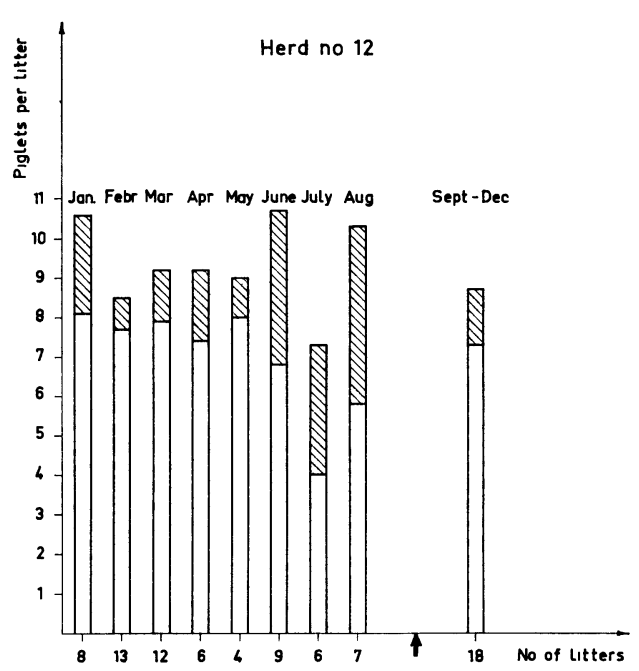

F i g u r e 2. Development of the disease in herd no. 12 measured by the rise in mortality. (The columns show the average number of piglets per litter at birth; the shaded parts show the average number of deaths; arrow indicates institution of specific prophylaxis).

started in June. The average mortality among 43 litters born between January 1 and June 1 was 1.4 piglets per litter (15.2\%), whereas among 22 litters born from June 1 to September 1 there was an average of 3.9 deaths per litter (39.7\%). Among 18 litters born between September 1 and December 31 the average mortality was again 1.4 piglets per litter $(16.1 \%)$. Specific prophylaxis was commenced at the end of August.

Litter mortality and morbidity. In 128 litters from 24 infected herds 1,283 piglets were born alive, and 693 of these died. This corresponds to an average mortality of $54 \%$.

In 8 herds the mortality was roughly estimated to be 25 to $80 \%$, and it was stated that a few litters had not been affected and that in some litters all piglets had died.

The anamnestic data concerning the mortality in 24 herds are rendered in Fig. 3. It will be seen that the mortality varies considerably from litter to litter. There is also variation in the average mortality from herd to herd, but direct comparison between these figures is not possible, since the number of litters on which the calculation is based does not represent the same percentage of breeding sows in all herds. 


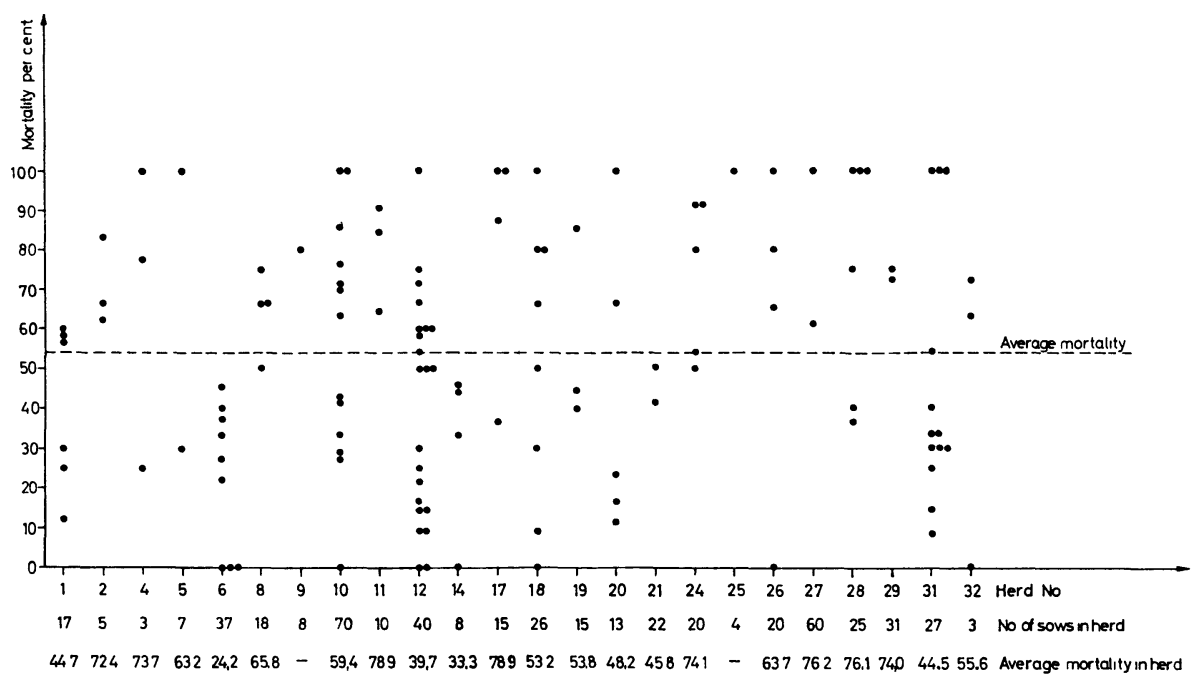

Figure 3. Anamnestic information concerning size of herd and piglet mortality in 24 herds of swine.

In 18 of the total of 128 litters $(14.1 \%)$ all the piglets died, and in 27 litters $(21.1 \%)$ the mortality varied from 0 to $25 \%$.

Influence of size of litter on mortality. The relationship between mortality and size of litter is shown in Fig. 4. Litters of $6-8$ and $13-15$ piglets are grouped together on account of

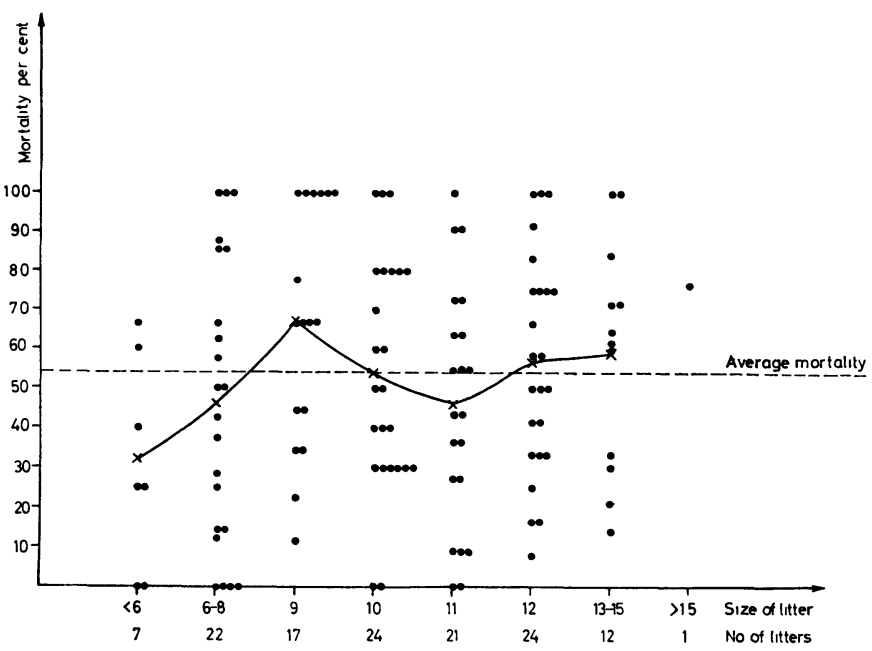

F i g u r e 4. Mortality in relation to size of litter. 


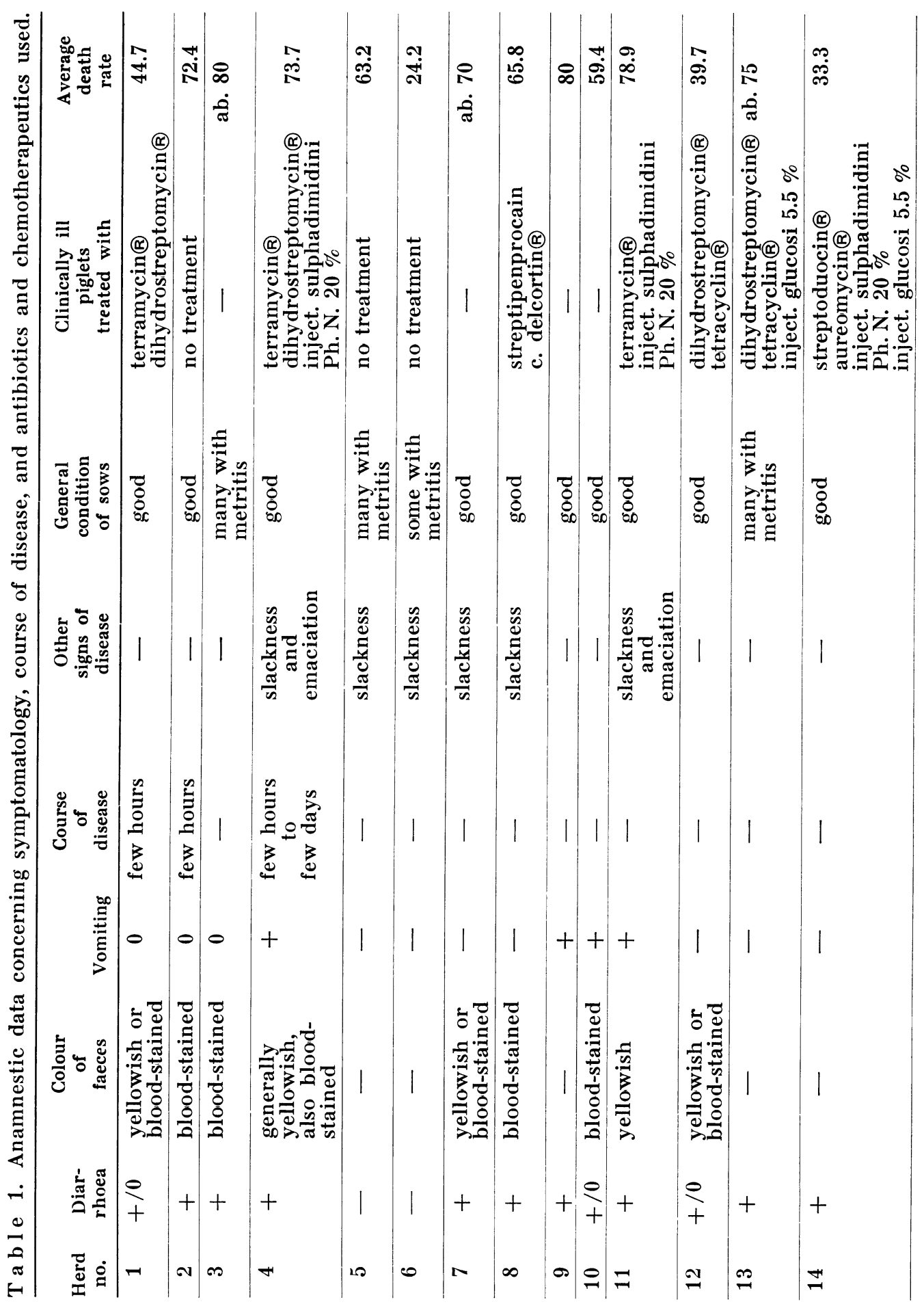




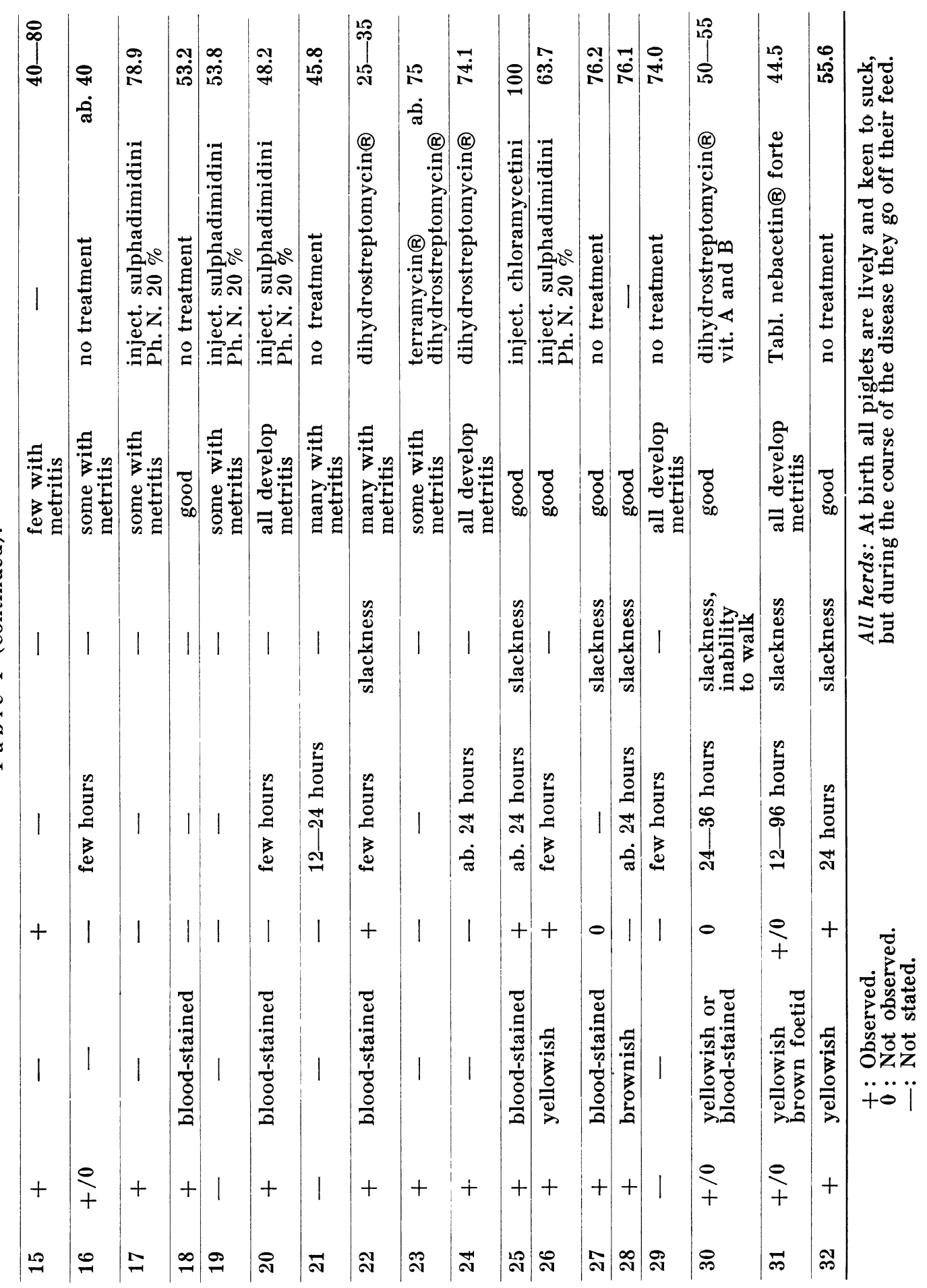


the low frequency with which these litter sizes are found in the material.

It will be seen from the figure that there is a great variation in the mortality of piglets in litters of the same size. The mortality was highest in litters with 9 piglets $(66.7 \%)$ and lowest in litters with $6-8$ and 11 piglets $(45.9 \%)$. The mortality in litters with 10,12 and $13-15$ piglets did not deviate much from the average $(54 \%)$ of all the litters.

Effect of the health condition of the sows on mortality in the herds. As will be seen from the anamnestic data in Table 1, the health of the sows was good in 17 of the herds, whereas in 15

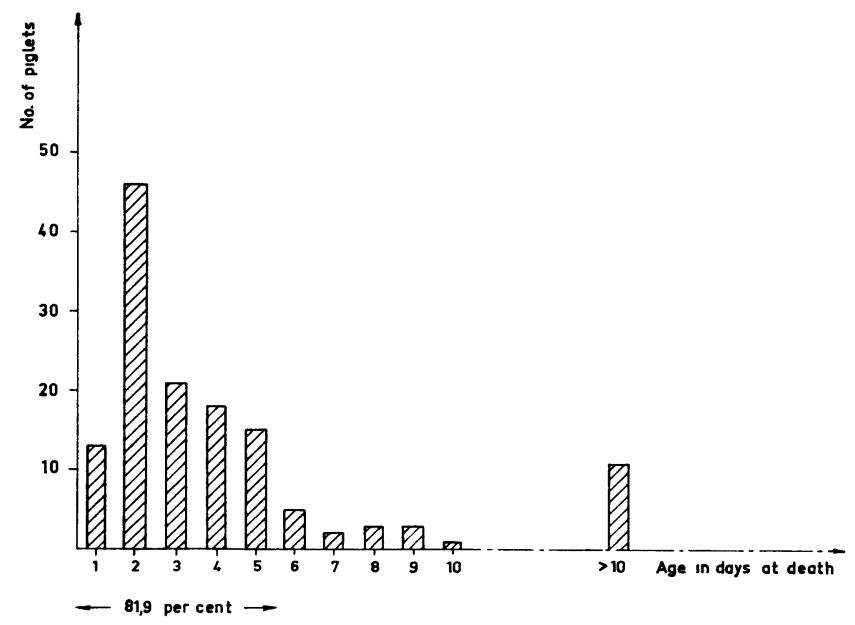

Figure 5. Age variation at death for 138 piglets examined.

herds many or all of the sows had metritis in connection with farrowing. In 10 of the 24 herds mentioned in Fig. 3, metritis occurred frequently; in these herds there were born 51 litters with 530 piglets of which 284 died $(53.6 \%)$ ). In the remaining 14 herds, where the health of the sows was found to be good, there were born 77 litters with 753 piglets of which 409 died $(54.3 \%)$.

Age of piglets at death. Fig. 5 shows the distribution according to age at death of 138 piglets in which characteristic pathoanatomical changes were found on necropsy.

As will be seen, $81.9 \%$ of the piglets died within the first 5 days of life. The mortality was greatest on the second day $(33.3 \%)$ and only $8 \%$ were more than 10 days old at the time of death. 
Fig. 6 gives anamnestic data from 30 herds concerning the variation in age at death in litters born during the period from the presumed onset of the disease until the diagnosis was established. As will appear from the figure deaths commenced when the piglets were $1-3$ days old. With the exception of herds nos. 12 and 16, where it was stated that deaths might occur up to an age of 3 weeks and 2 weeks respectively, deaths were seldom after the first week of life. As regards the litters in which deaths occurred over a period of several days, it was stated that the mortality was greatest in the beginning of the period, while only a few piglets died later.

Symptoms. According to the anamnestic details (Table 1), the piglets were apparently healthy at birth. They were lively and keen to suck during the first hours after birth. The time of onset of the disease varied from about $12 \mathrm{hrs}$. to 5-6 days after

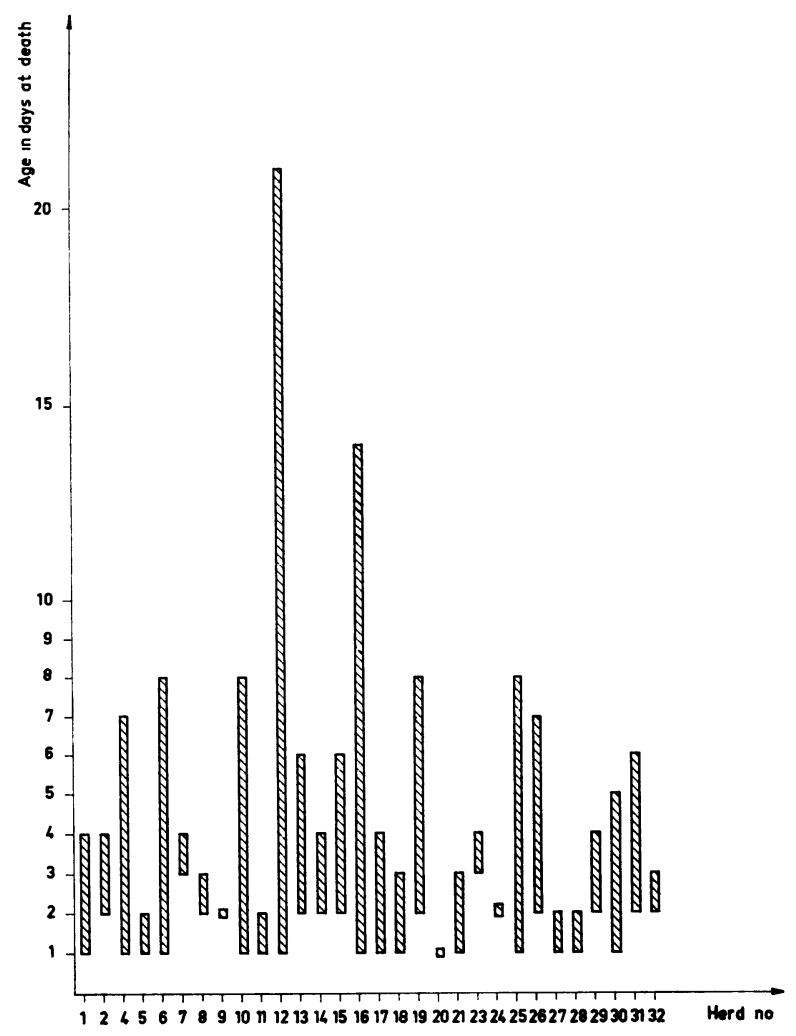

Figure 6. Anamnestic data concerning variation in age at death in 30 herds. 
birth. In the majority of cases the piglets became ill about 24 hrs. after birth. Occasionally they were 2 to 3 weeks old before symptoms appeared.

The affected piglets became listless and lay under the heating lamp or round about in the sty, often hidden in the bedding. The skin was dry and the coat bristly. At the root of the tail and in the anal region the skin was often soiled with faeces. The abdomen was slightly distended, giving the piglets a "paunchy" appearance. Simultaneously with the disturbances in the general condition, the piglets lost their desire to suck. In the majority of cases there was diarrhoea and sometimes vomiting. The colour and consistency of the faeces varied. In some instances the faeces were curry-coloured and of a gruel-like consistency, in others they were more or less blood-stained, watery, and of a colour varying from brownish to red (lacquer red). In the latter cases the faeces often consisted entirely of haemolysed blood. Sometimes the faeces were frothy and foetid.

The affected piglets were reluctant to move. When they did move, they had a kyphotic posture and a very uncertain, staggering gait and would fall over at the slightest push.

At first respiration was normal, but during the course of the disease it became difficult. Towards the final stages particularly the expiration was laboured and jerky.

Shortly before death the piglets would lie quite still. In this moribund stage generalized fibrillar muscle cramps could be observed, and occasionally irregular "cycling" movements of the extremities.

The body temperature was generally normal, but might vary from subnormal to subfebrile. In a spontaneous outbreak in herd no. 22 variation from $37.3^{\circ} \mathrm{C}$ to $38.0^{\circ} \mathrm{C}$ was observed in 5 affected piglets about $10 \mathrm{hrs}$. after the onset of symptoms. The piglets died within $16 \mathrm{hrs}$. of the measurement of the temperature. In an outbreak in herd no. 29, 1 moribund piglet in a litter had a temperature of $35.5^{\circ} \mathrm{C}$, while the other 4 , which were clinically normal, had temperatures from $38.6^{\circ} \mathrm{C}$ to $39.1^{\circ} \mathrm{C}$.

In the infection experiment, 1 piglet with subacute disease showed a rise in temperature from $38.1^{\circ} \mathrm{C}$ about $10 \mathrm{hrs}$. after birth to $40.0^{\circ} \mathrm{C} 1$ day after the onset of illness. The temperature of 1 piglet with peracute disease fell from $38.1^{\circ} \mathrm{C}$ to $37.0^{\circ} \mathrm{C}$ about 3 hrs. before death. The temperatures of the in-contacts varied from $37.7^{\circ} \mathrm{C}$ to $38.6^{\circ} \mathrm{C}$. 
Course of disease. Information concerning the course of the disease is available for 15 herds only (Table 1). By comparing these data with the age of the piglets at death (Figs. 5 and 6), it can be seen that the infection generally took a peracute course. The animals would be lively and keen to suck in the evening and be moribund or dead the next morning.

The shortest course observed in the infection experiment was $7 \mathrm{hrs}$. (piglet $14-2$ ). After an incubation period of $11 \mathrm{hrs}$. this piglet had diarrhoea with brownish-yellow, slightly blood-stained faeces. It declined to suck when milk was offered $1 / 2 \mathrm{hr}$. later. After a further 2 hrs. (131/2 hrs. after infection) there was vomiting, and the faeces were haemorrhagic and watery. The animal was listless and slack, and after a period of increasing limpness it died $18 \mathrm{hrs}$. after the infection.

More rarely the disease lasted for several days (subacute course).

The longest course of disease observed in the infection experiment was 3 days (piglet $14-5$ ). After an incubation period of about $40 \mathrm{hrs}$. this piglet was very quiet. It had diarrhoea with yellowish, frothy, foetid faeces. It had no inclination to suck. This condition remained clinically unchanged until death occurred about 115 hrs. after infection.

Particularly in the subacute disease, the piglets became very thin, sharp-spined, dehydrated, and anaemic. The affected animals were considerably smaller than the others in the litter, but often participated in the meals. The faeces were often yellowish or greyish, watery or creamy, frothy and foetid. After several days even the subacute cases ended fatally.

Prognosis. The data available did not allow of any exact statement about the morbidity within the affected litters. Any exact prognosis based on the ratio between morbidity and mortality is therefore not possible.

The in-contacts in the infection experiment did not show clinical signs of disease, even though $\mathrm{Cl}$. perfringens type $\mathrm{C}$ could be isolated from rectal swabs. This may give reason to believe that many of the surviving pigs in the affected herds have shown no clinical symptoms. On this background, and taking into account the high average mortality $(54 \%)$, there would appear to be only a poor chance of recovery for clinically diseased piglets. This seems to apply whether clinical cases are treated or not (Table 1). 
In 13 herds in which one or more of the drugs mentioned in Table 1 were used, 765 piglets were born, and 400 of these, or $52.3 \%$, died despite treatment. In 8 herds in which no treatment was given, 308 piglets were born, 155 of which died, i.e. a mortality of $50.3 \%$.

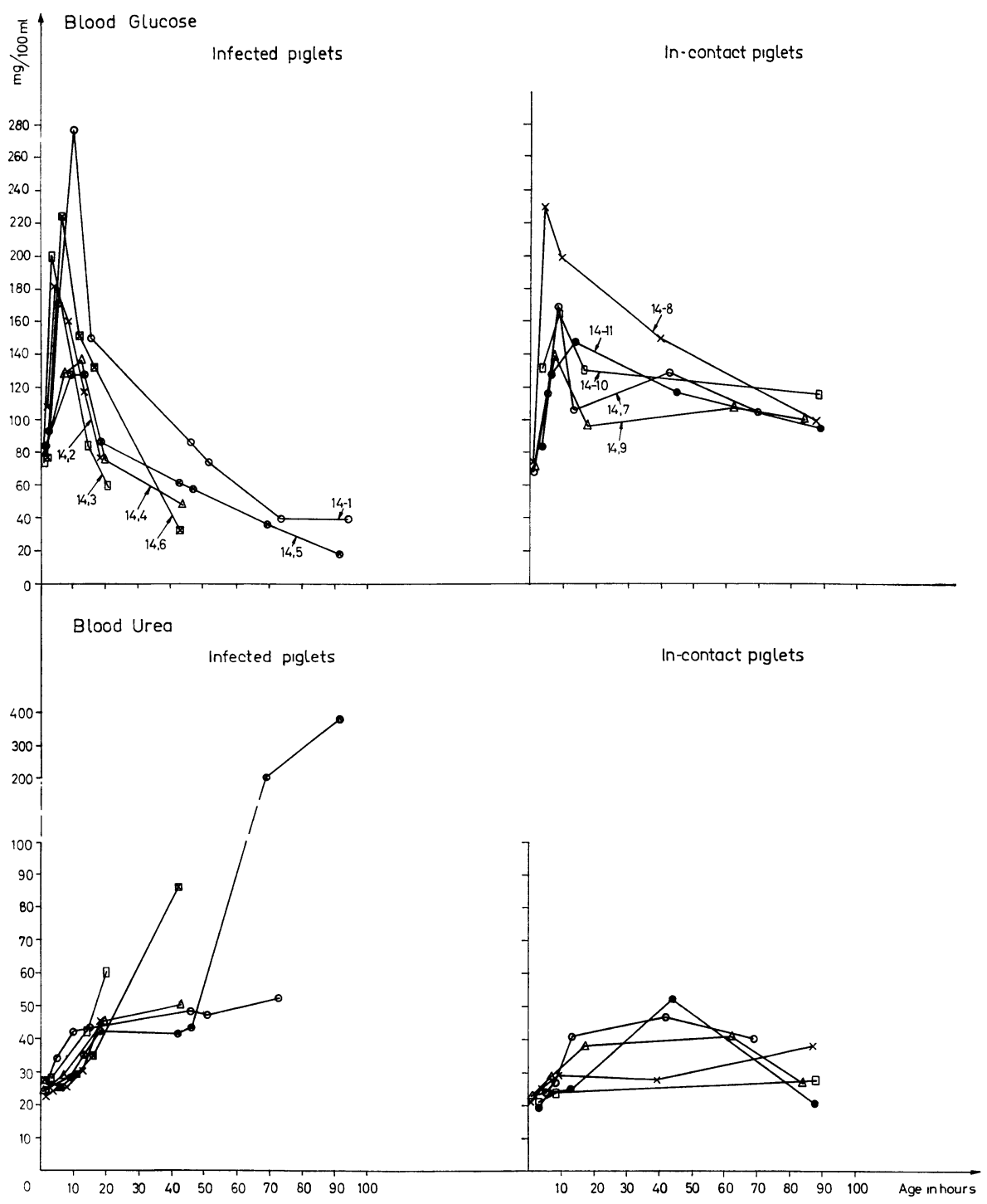

Figure 7. Blood glucose and blood urea in experimentally infected and in-contact piglets. 


\section{Examination of blood}

The results of the biochemical examinations of plasma from the piglets in the infection experiment are shown in Fig. 7. It will be seen that, after an initial increase, the glucose content fell to between 100 and $120 \mathrm{mg} / 100 \mathrm{ml}$ in the in-contacts. In the infected piglets, the glucose content fell much more rapidly and to extremely low values shortly before death. The longer the course of disease, the lower glucose levels were reached.

Blood urea was somewhat higher in the infected piglets than in the in-contacts. Uraemic values $(200-380 \mathrm{mg} / 100 \mathrm{ml})$ were found in one of the infected piglets $1-2$ days before death.

Plasma glucose levels of $28-86 \mathrm{mg} / 100 \mathrm{ml}$ and blood urea levels of $54-69 \mathrm{mg} / 100 \mathrm{ml}$ were found in 5 piglets in the spontaneous outbreak in herd no. 22 (Table 2).

The erythrocyte counts and the haematocrit and haemoglobin percentages in the piglets in the infection experiment and in 13 normal piglets are shown in Fig. 8. It will be seen that the initial values were somewhat higher in the piglets in the infection experiment than in the normal animals. From 5 to $20 \mathrm{hrs}$. after

T a b l e 2. Clinical, biochemical, and haematological examination of blood from piglets during spontaneous outbreak (herd no. 22).

\begin{tabular}{ccccccccr}
\hline $\begin{array}{c}\text { Piglet } \\
\text { no. }\end{array}$ & $\begin{array}{c}\text { Glucose } \\
\mathrm{mg} / \\
100 \mathrm{ml}\end{array}$ & $\begin{array}{c}\text { Urea } \\
\mathrm{mg} / \\
100 \mathrm{ml}\end{array}$ & $\begin{array}{c}\text { Haemo- } \\
\text { globin } \\
\mathrm{g} /\end{array}$ & $\begin{array}{c}\text { Haema- } \\
\text { tocrit } \\
\%\end{array}$ & $\begin{array}{c}\text { Erythro- } \\
\text { cytes } \\
\text { millions } \\
\text { per } \mathrm{mm}^{3}\end{array}$ & $\begin{array}{c}\text { Leukocytes } \\
\text { thousands } \\
\text { per mm }\end{array}$ & $\begin{array}{c}\text { Lympho- } \\
\text { cytes }\end{array}$ & $\begin{array}{r}\text { Mono- } \\
\text { cytes }\end{array}$ \\
\hline $16-1$ & 86 & 58 & 6.9 & 23.7 & 3.4 & - & - & - \\
$16-2$ & 53 & 54 & - & - & - & - & - & - \\
$16-3$ & 28 & 69 & 14.2 & 46.3 & 6.2 & 6.8 & 2652 & 136 \\
$17-1$ & 42 & 67 & 11.5 & 42.2 & 4.2 & 7.6 & 3268 & 152 \\
$17-2$ & 38 & 69 & 11.2 & 41.2 & 4.7 & 12.9 & 3612 & 0 \\
\hline
\end{tabular}

T a ble 2 (continued).

\begin{tabular}{crccc}
\hline & \multicolumn{4}{c}{ Granulocytes } \\
\cline { 2 - 5 } $\begin{array}{c}\text { Piglet } \\
\text { no. }\end{array}$ & $\begin{array}{c}\text { Hetero- } \\
\text { philic }\end{array}$ & $\begin{array}{c}\text { Eosino- } \\
\text { philic }\end{array}$ & $\begin{array}{c}\text { Baso- } \\
\text { philic }\end{array}$ & $\begin{array}{c}\text { Juvenile } \\
\text { hetero- } \\
\text { philic }\end{array}$ \\
\hline $16-1$ & - & - & - & - \\
$16-2$ & - & - & - & - \\
$16-3$ & 136 & 0 & 0 & 3876 \\
$17-1$ & 76 & 0 & 0 & 4104 \\
$17-2$ & 258 & 0 & 0 & 9030 \\
\hline
\end{tabular}



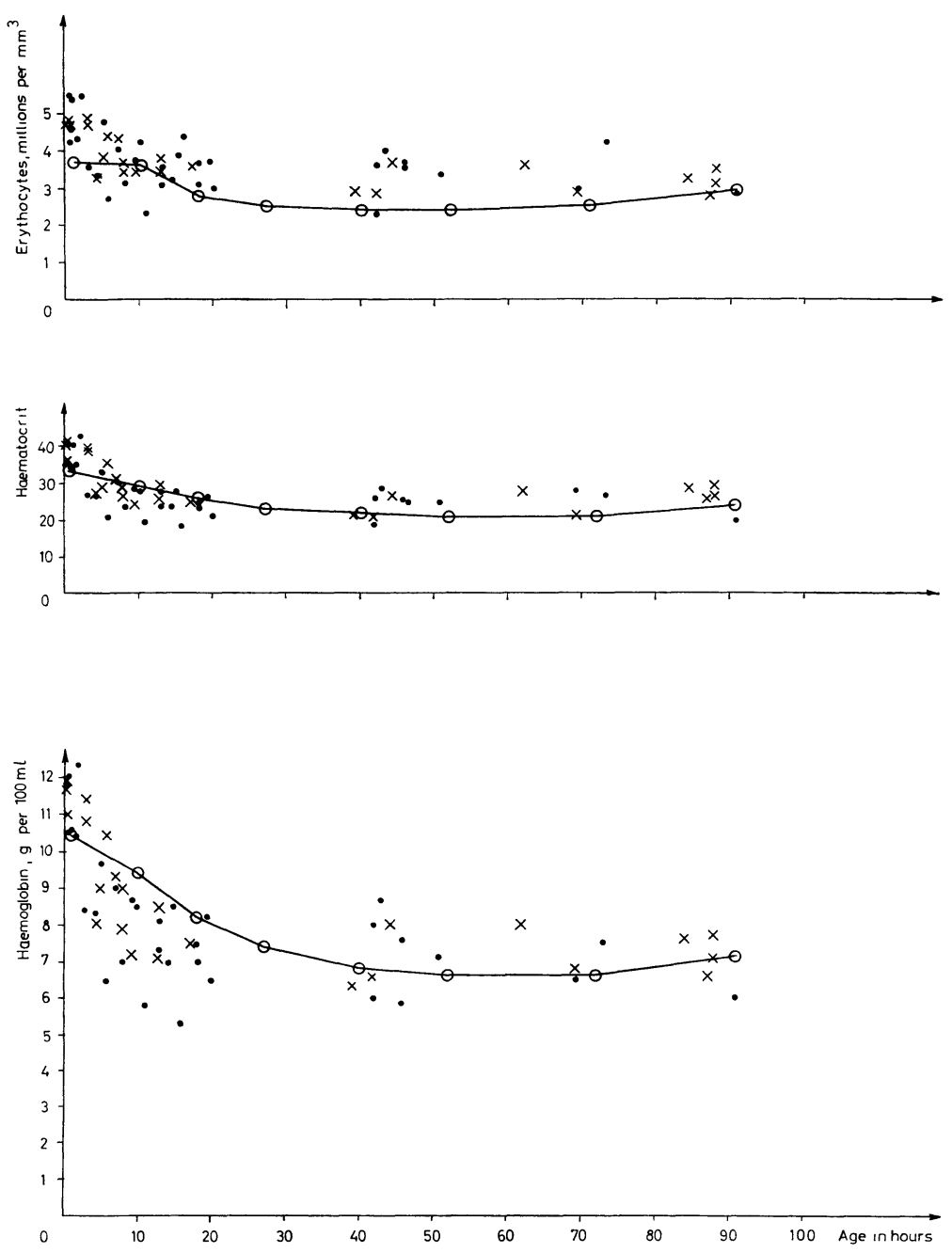

Figure 8. Erythrocyte counts, haematocrit and haemoglobin percentages in infected, in-contact, and normal piglets. $(\cdot:$ infected piglets, $\mathrm{x}$ : in-contact piglets, $\odot-\odot:$ normal piglets).

birth both haematocrit and haemoglobin percentages were lower in the experimental animals than in the normal piglets. The differences observed between in-contacts and infected piglets were not significant.

About 10 hrs. after the onset of disease, 4 of the piglets in herd no. 22 (Table 2) showed erythrocyte counts and haematocrit and haemoglobin percentages similar to the initial values shown in Fig. 8. 
T a ble 3. Total and differential leukocyte counts in infected, incontact, and normal piglets.

\begin{tabular}{|c|c|c|c|c|c|c|c|c|}
\hline \multirow[b]{2}{*}{ Piglet no. } & \multirow[b]{2}{*}{$\begin{array}{l}\text { Age in } \\
\text { hours }\end{array}$} & \multirow[b]{2}{*}{$\begin{array}{c}\text { Leuko- } \\
\text { cytes } \\
1000 / \mathrm{mm}^{3}\end{array}$} & \multirow[b]{2}{*}{$\begin{array}{l}\text { Lympho- } \\
\text { cytes }\end{array}$} & \multirow[b]{2}{*}{$\begin{array}{l}\text { Mono- } \\
\text { cytes }\end{array}$} & \multicolumn{4}{|c|}{ Granulocytes } \\
\hline & & & & & $\begin{array}{c}\text { Hetero- } \\
\text { philic }\end{array}$ & $\begin{array}{c}\text { Eosino- } \\
\text { philic }\end{array}$ & $\begin{array}{l}\text { Baso- } \\
\text { philic }\end{array}$ & $\begin{array}{l}\text { Juvenile } \\
\text { hetero- } \\
\text { philic }\end{array}$ \\
\hline \multirow[t]{2}{*}{$14-2$} & $\left.1.5^{\star}\right)$ & 8.9 & 3110 & 0 & 5590 & 180 & 0 & 0 \\
\hline & 4 & 19.0 & 2850 & 0 & 16150 & 0 & 0 & 0 \\
\hline \multirow{4}{*}{$\begin{array}{l}\text { Peracute } \\
\text { course }\end{array}$} & 8 & 25.4 & 6350 & 0 & 17780 & 0 & 0 & 1270 \\
\hline & 13 & 16.6 & 6970 & 0 & 7970 & 0 & $\mathbf{0}$ & 1660 \\
\hline & 18 & 7.0 & 3180 & 0 & 2350 & 70 & 0 & 1400 \\
\hline & $20 \mathrm{mo}$ & ors & & & & & & \\
\hline \multirow[t]{3}{*}{$14-5$} & $\left.1^{\star}\right)$ & 6.8 & 2580 & 0 & 4150 & 70 & 0 & 0 \\
\hline & 9 & 24.7 & 6422 & 618 & 13462 & 124 & 0 & 3974 \\
\hline & 13 & 11.2 & 2800 & 336 & 6272 & 0 & 0 & 1792 \\
\hline Subacute & 18 & 16.2 & 3645 & 243 & 10773 & 0 & 0 & 1539 \\
\hline \multirow[t]{7}{*}{ course } & 42 & 4.1 & 779 & 123 & 369 & 0 & 0 & 2829 \\
\hline & 46 & 2.6 & 754 & 13 & 156 & 0 & 0 & 1677 \\
\hline & 69 & 14.4 & 2520 & 0 & 0 & 0 & 0 & 11880 \\
\hline & 91 & 12.5 & 3250 & 0 & 0 & 0 & 0 & 9250 \\
\hline & ab. $115 \mathrm{mo}$ & ors & & & & & & \\
\hline & $\left.0-2^{\star \star}\right)$ & 8.5 & 2793 & 0 & 5597 & 27 & 0 & 37 \\
\hline & $3-10$ & 21.6 & 5537 & 0 & 15512 & 90 & 0 & 514 \\
\hline \multirow[t]{6}{*}{ In-contacts } & $11-20$ & 24.6 & 5264 & 0 & 18968 & 401 & 0 & 0 \\
\hline & $36-46$ & 16.2 & 5637 & 0 & 9923 & 247 & 0 & 427 \\
\hline & $60-75$ & 12.5 & 5685 & 0 & 6515 & 0 & 0 & 300 \\
\hline & $80-90$ & 19.9 & 8068 & 0 & 8548 & 0 & 0 & 3055 \\
\hline & $\left.0-2^{\star \star}\right)$ & 14.4 & 4978 & 93 & 9059 & 0 & 0 & 256 \\
\hline & $3-10$ & 24.8 & 3414 & 304 & 19755 & 42 & 0 & 1265 \\
\hline & $11-20$ & 17.2 & 4403 & 220 & 12000 & 36 & 6 & 528 \\
\hline \multirow[t]{4}{*}{ piglets } & $36-46$ & 11.9 & 5634 & 8 & 5740 & 27 & 4 & 477 \\
\hline & $47-55$ & 14.0 & 6445 & 74 & 7252 & 20 & 5 & 214 \\
\hline & $60-75$ & 17.4 & 5852 & 8 & 10867 & 117 & $\mathbf{0}$ & 560 \\
\hline & $80-90$ & 22.5 & 6410 & 0 & 11915 & 42 & 0 & 847 \\
\hline
\end{tabular}

*) Blood sample before infection and before feeding colostrum.

**) Blood sample before feeding colostrum.

In Table 3 total and differential white blood cell counts are given for a pig with peracute $(14-2)$ and one with subacute $(14-5)$ disease. The average values for the in-contact and normal piglets are also given.

It will be seen from the table that in its peracute course the disease was associated with a precipitous fall in the number of 
leukocytes just before death. This fall applied to both lymphocytes and heterophils. The relative increase in the number of juvenile heterophils was not able to compensate for the leukopenia thus developed.

In the subacute course, considerable leukopenia involving both lymphoid and myeloid cells developed about $40 \mathrm{hrs}$. after the infection. Later in the disease the number of lymphocytes increased to about half the number observed at the same time in the in-contact and normal piglets. The lack or complete absence of mature heterophils was to some extent counterbalanced by a violent increase in the number of juvenile heterophils. Eosinophils, found regularly in normal piglets, were observed only sporadically in infected piglets.

There was eosinopenia in the in-contact pigs $60-75$ hrs. after birth. In these animals also there was an increase in the number of juvenile heterophils corresponding to about $25 \%$ of the total number of heterophils normally found $80-90 \mathrm{hrs}$. after birth.

Leukopenia and shift to the left of heterophils, as well as eosinopenia, were seen in the spontaneous outbreak in herd no. 22 (Table 2).

Some normoblasts were observed in both infected, in-contact, and normal piglets. Annulocytosis, poikilocytosis and metachromasia were often found after 3 to 4 samplings.

On closer examination of the heterophils a marked granulation was seen in some of the cells, but there was no definite evidence of toxic damage. Most of the juvenile heterophils had band-shaped nuclei, but more primitive myeloid cell forms were also seen.

\section{DISCUSSION}

The localization of the infected herds of swine shows that necrotizing enteritis in piglets occurs enzootically in Denmark. A direct trade connection between infected herds in Zealand and Jutland has not been proved, but it is known that there is quite an extensive sale of weanling pigs from Zealand to Jutland.

Under practical conditions, it is assumed that the average mortality among piglets in Danish herds is 20 to $25 \%$ (Clausen 1967). The mortality in the 24 herds dealt with in Fig. 3 being calculated on the basis of information about births and deaths, while dead piglets have generally not been examined more thoroughly, it is probable that up to about $25 \%$ of these piglets 
will have died from causes other than infection with $\mathrm{Cl}$. perfringens type $\mathrm{C}$.

Even slight changes in the mortality observed in litters of a given size (Fig. 4) would approximate the curve to the average mortality calculated for all 128 litters. A deduction of up to $25 \%$ "non-specific" mortality would not alter the course of the curve to any extent. Thus the mortality would seem to be independent of the size of litter.

As reported by Laskowski et al. (1957), colostrum from sows contains considerable amounts of a trypsin inhibitor for up to 5 days after farrowing. Since the mortality due to $\mathrm{Cl}$. perfringens type $\mathrm{C}$ is greatest in that period (Fig. 5), the presence of the trypsin inhibitor may well be of pathogenetic significance, as suggested by Griner (1963).

The symptoms observed correspond to those described by Field \& Gibson (1955) and Szent-Iványi \& Szabó (1956) though in some cases the clinical picture was characterized by symptoms of gastro-enteritis.

Diarrhoea with haemorrhagic faeces, or faeces consisting mainly of haemolysed blood, is an important clinical symptom from the point of view of differential diagnosis. Cases showing diarrhoea with yellowish or greyish, gruel-like to creamy faeces cannot be distinguished clinically from Escherichia coli infections (Gordon \& Luke 1958, Saunders et al. 1960). Even though enteric coli infection is more often seen in 6-12-week-old piglets (Dam $\&$ Knox 1962), this disease occurs so frequently also among newborn piglets in this country that it must be looked upon as the most important differential diagnostic problem. Also morbus Aujeszkyi is of significance in that respect in Denmark. This disease, however, is not accompanied by diarrhoea but characterized by nervous disturbances (Andersen et al. 1964, Bendixen $\&$ Borgen 1965) and the mortality is greatest in the second week of life (Bitsch 1967). Cases with severe gastro-enteritis and dehydration can be mistaken for transmissible gastro-enteritis (Doyle \& Hutchings 1946, Bay et al. 1949). This disease, which has been diagnosed clinically in Denmark (Knox 1957), is different from necrotizing enteritis in that it attacks pigs of all ages. It is true that necrotizing enteritis caused by $\mathrm{Cl}$. perfringens type $\mathrm{C}$ has been diagnosed also in weanling (Mészáros \& Pesti 1965) and fattening pigs (Estola \& Stenberg 1963); under Danish con- 
ditions, however, it is typical that the disease is occurring in the neonatal period.

Also hypoglycaemia must be taken into account in differential diagnosis. Unlike necrotizing enteritis, however, hypoglycaemia, which is often due to primary or secondary agalactia, can be cured by injections of glucose (Goodwin 1955) and prevented by adequate treatment of the sows. Metritis in connection with farrowing was reported to be common in ab. half the infected herds examined; the owners maintained, however, that sows with affected litters had a plentiful supply of milk, but that "the piglets could not stand it".

The hypoglycaemia seen in piglets with necrotizing enteritis is presumably due partly to anorexia, partly to an impaired absorption from the intestinal canal, and the increased blood urea is suggestive of renal dysfunction. The low haematocrit and haemoglobin percentages observed 5-20 hrs. after birth in the piglets in the infection experiment are probably provoked by frequent blood sampling.

The eosinopenia and the increase in the number of juvenile heterophilic granulocytes observed in the in-contact piglets $80-90$ hrs. after birth are presumably caused by the latent infection which was demonstrated in these piglets.

The eosinopenia observed points to an acute stress effect, and the development of leukopenia to a severe consumption of both lymphocytes and heterophils. The organism will try to compensate for this loss by an increased production of white blood cells, as can be seen both in peracute and subacute cases.

In peracute cases the increase in the number of juvenile heterophils cannot offset this consumption. This would seem to be suggestive of a toxic effect on the red bone marrow with subsequent heteropenia. In subacute cases the leukopenia is to some degree compensated for, partly by an increased production of lymphocytes, partly by a marked increase in the number of juvenile heterophils. However, this increase cannot quite offset the consumption.

\section{ACKNOWLEDGMENTS}

The author is indebted to Drs. P. Slot, N. Friis, and J. Bech for professional help with the biochemical and haematologic examinations, and to Mrs. I. Hansen, Mrs. V. Riis, and Miss J. Weis for technical assistance. 


\section{REFERENCES}

Andersen, H. K., A. Basse \& T. Møller: Enzootisk optrædende morbus Aujeszky hos pattegrise. Medlemsbl. danske Dyrlægeforen. 1964, 47, 968-978.

Bakhtin, A. G.: Dysentery of new-born piglets. Veterinariya Moscow 1956, 33, 30-32.

Barnes, D. M. \& H. W. Moon: Enterotoxemia in pigs due to Clostridium perfringens type C. J. Amer. vet. med. Ass. 1964, 144, 1391-1394.

Bay, W. W., L. M. Hutchings, L. P. Doyle \& Doris E. Bunnell: Transmissible gastroenteritis in baby pigs. J. Amer. vet. med. Ass. $1949,115,245-248$.

Bendixen, H. J. \& H. C. Borgen: Morbus Aujeszkyi's forekomst og optræden hos svin i Danmark. Nord. Vet.-Med. 1965, 17, 657-671.

Bitsch, V.: Personal communication, 1967.

Brown, H. H.: Determination of blood urea with p-dimethylaminobenzaldehyde. Analyt. Chem. 1959, 31, 1844-1846.

Carle, B. N. \& Wm. H. Dewhirst: A method for bleeding swine. J. Amer. vet. med. Ass. 1942, 101, 495-496.

Clausen, Hj.: Personal communication, 1967.

Dam, A. \& Betty Knox: Om forekomsten af hæmolytiske Escherichiae coli i forbindelse med enteritis og enterotoxæmi hos svin. IX. Nord. Vet.-møde, København 1962, 277-282.

Doyle, L. P. \& L. M. Hutchings: A transmissible gastroenteritis in pigs. J. Amer. vet. med. Ass. 1946, 108, 257-259.

Estola, T. \& H. Stenberg: Om förekomsten av klostridier hos husdjur och i animaliska produkter. Nord. Vet.-Med. 1963, 15, 35-47.

Field, H. I. \& E. A. Gibson: Studies on piglet mortality. 2. Clostridium welchii infection. Vet. Rec. 1955, 67, 31-35.

Field, H. I. \& R. F. W. Goodwin: The experimental reproduction of enterotoxaemia in piglets. J. Hyg. (Lond.) $1959,57,81-91$.

Goodwin, R. F. W.: Some common factors in the pathology of the newborn pig. Brit. vet. J. 1955, 111, 361-372.

Gordon, W.A.M.\& D. Luke: Gastroenteritis in young piglets associated with Escherichia coli. Vet. Rec. 1958, 70, 542-543.

Griner, $L$. A.: Some factors influencing the incidence of enterotoxemia in domestic animals. Bull. Off. int. Épiz. 1963, 59, 1443-1451.

$H \phi g h, P .:$ Enterotoksæmi hos pattegrise forårsaget af Clostridium perfringens type C. Foreløbig meddelelse. Nord. Vet.-Med. 1965, 17, $1-8$.

$H \phi g h, P .:$ Necrotizing infectious enteritis caused by Clostridium perfringens type C. I. Biochemical and toxigenic properties of the clostridium. Acta vet. scand. 1967, 8, 26-38.

Knox, Betty: Ny pattegrisesygdom i Danmark. Medlemsbl. danske Dyrlægeforen. 1957, 40, 636-639.

Laskowski, M., B. Kassell \& G. Hagerty: A crystalline trypsin inhibitor from swine colostrum. Biochim. biophys. Acta 1957, 24, 300305.

Levin, K. \& S. Linde: Bestämning av glycos i blod, liquor och urin med ett nytt glycosoxidasreagens. Svenska Läk.-Tidn. 1962, 59, 30163026 . 
Levine, J. M., R. Leon \& F. Steigmann: A rapid method for the determination of urea in blood and urine. Clin. Chem. 1961, 7, 488493.

Manninger, R.: Entérite nécrosante infectieuse des porcelets à la mamelle. Bull. Off. int. Épiz. 1960, 54, 178-180.

Mészáros, J. \& L. Pesti: Studies on the pathogenesis of gastroenteritis in swines. Acta vet. Acad. Sci. hung. 1965, 15, 465-470.

Moon, H. W. \& M. E. Bergeland: Clostridium perfringens type C enterotoxemia of the new-born pig. Canad. vet. J. 1965, 6, 159 161.

Saunders, C. N., A. J. Stevens, J. B. Spence \& W. J. Sojka: Escherichia coli infection in piglets. Res. vet. Sci. $1960,1,28-35$.

Szent-Iványi, Th. \& St. Szabó: Infectious necrotic enteritis of sucking pigs. I. Etiology and pathology. Acta vet. Acad. Sci. hung. 1956, $6,217-229$.

\section{SUMMARY}

Necrotizing enteritis in piglets caused by Clostridium perfringens type $\mathrm{C}$ has been diagnosed in 32 Danish herds of swine (status as at March 1, 1967), the geographical location of which (Fig. 1) shows the enzootic character of the disease. The disease occurs both in small and large herds, and is characterized by a high mortality during the first week of life (Fig. 5). The mortality does not seem to be influenced either by the size of litter (Fig. 4) or by the state of health of the sows (Table 1).

After an incubation period varying from a few hours to a few days, the piglets develop symptoms of enteritis or gastro-enteritis with general malaise and anorexia. The disease, the course of which varies from about $12 \mathrm{hrs}$. to a few days, ends in coma and death. The body temperature usually remains normal, but may be subnormal or subfebrile.

The disease is accompained by hypoglycaemia and increased blood urea (Fig. 7). In peracute cases there is leukopenia, with some shift to the left of the heterophilic granulocytes. There is also leukopenia in subacute cases, but as regards the heterophils this is partly offset by a marked increase in the number of juvenile heterophils. Eosinopenia is another characteristic haematological finding (Table 3).

In the differential diagnosis; special attention should, under Danish conditions, be paid to $E$. coli infections in new-born piglets.

\section{ZUSAMMENFASSUNG}

Infektiöse nekrotisierende Enteritis bei Saugferkeln hervorgerufen von Clostridium perfringens Typ C. II. Auftreten und klinische Befunde.

Nekrotisierende Enteritis bei kleinen Saugferkeln ist in 32 dänischen Schweinebeständen diagnostiziert worden (Status am 1/3 1967). Die geographische Plazierung der Bestände (Fig. 1) zeigt das 
enzootische Auftreten der Krankheit. Die Krankheit, die sowohl in grossen wie in kleinen Schweinebeständen auftritt, ist durch eine grosse Sterblichkeit in der ersten Lebewoche (Fig. 5) charakterisiert. Die Grösse des Wurfes (Fig. 4) und der Gesundheitszustand der Säue (Tabelle 1) scheint nicht die Sterblichkeit zu beeinflussen.

Nach einer Inkubationszeit, die sich über einige Stunden bis auf wenige Tage erstreckt, zeigen die Ferkel Enteritis- oder Gastroenteritissymptome mit gestörtem Allgemeinbefinden und Anorexie. Der Krankheitsverlauf, der sich von etwa 12 Stunden bis uber einige Tage erstrecken kann, endet mit Coma und Tod. Die Körpertemperatur ist im allgemeinen normal, kann jedoch subnormal oder subfebril sein.

Die Krankheit folgen Hypoglykämie und erhöhte Blutharnstoffwerte (Fig. 7). Bei dem perakut-akutten Verlauf tritt Leukopenie mit etwas Linksverschiebung der heterophilen Granulozyten auf. Der subakutte Verlauf wird ebenfalls von Leukopenie begleitet. Hier wird die veränderte Menge der heterophilen Granulozyten jedoch zum Teil durch eine erhebliche Steigerung im Auftreten von juvenilen heterophilen Granulozyten kompensiert. Eosinopenie ist ebenfalls ein charakteristischer hämatologischer Befund (Tabelle 3).

Unter dänischen Verhältnissen spielt die E. coli Infektion bei neugeborenen Ferkeln die grösste Rolle bei der Differentialdiagnostik.

\section{SAMMENDRAG}

Infektiøs nekrotiserende enteritis hos pattegrise forårsaget af Clostridium perfringens type C. II. Forekomst og kliniske fund.

Nekrotiserende enteritis hos spæde pattegrise er diagnosticeret i 32 danske svinebesætninger (status pr. 1/3 1967), hvis geografiske placering (Fig. 1) viser sygdommens enzootiske optræden. Sygdommen, der ses såvel i små som i store svinebesætninger, er karakteriseret ved høj mortalitet i den f $\varnothing$ rste leveuge (Fig. 5). Kuldst $\varnothing$ rrelse (Fig. 4) og søernes sundhedstilstand (Tabel 1) synes ikke at influere på mortaliteten.

Efter en inkubationstid på få timer til få dage får grisene symptomer på enteritis eller gastroenteritis med forstyrret almenbefindende og anorexi. Sygdomsforløbet, der kan variere fra ca. 12 timer til få dage, ender i coma og mors. Legemstemperaturen er i reglen normal, men kan være subnormal eller subfebril.

Sygdommen ledsages af hypoglycæmi og forh $\varnothing j e d e$ blodurinstofværdier (Fig. 7). Ved det perakut-akutte forl $\emptyset b$ ses leukopeni med nogen venstreforskydning af de heterofile granulocyter. Det subakute forl $\varnothing b$ ledsages ligeledes af leukopeni, der dog for de heterofile granulocyters vedkommende i nogen grad kompenseres af en voldsom stigning $i$ forekomsten af juvenile heterofile granulocyter. Eosinopeni er ligeledes et karakteristisk hæmatologisk fund (Tabel 3).

Under danske forhold spiller E. coli infektion hos nyf $\varnothing$ dte grise den væsentligste rolle $\mathrm{i}$ differentialdiagnostisk henseende. 